\title{
Empirical and finite element based stability analysis of highway cut slopes in Uttarakhand Himalayan terrain, India
}

\author{
Hari Om Singh* ${ }^{*}$, Tariq Anwar Ansari, T. N. Singh and K. H. Singh
}

*Correspondence:
hsagl.iitb@gmail.com
Department of Earth
Sciences, Indian Institute
of Technology Bombay,
Mumbai, Maharashtra, India

${ }^{*}$ Correspondence: hsagl.iitb@gmail.com Sciences, Indian Institut Mumbai, Maharashtra, India

\begin{abstract}
The present paper deals with different empirical methods and finite element method of slope stability analysis along National Highway (NH)-7, in Uttarakhand, India. The highway is only path in the hilly terrain of Lesser Himalayan for the public transport and have strategic importance due to militaries possession routes. This route is also significant due to having many holistic places, connecting to this. There was numerous landslides happened along the Highway in past due to various natural and anthropogenic activities. Hence, keeping an eye to the socio-economic development of the distant area, slope stability analysis is very crucial along the road cut sections. To identify the vulnerable locations and to collect the geotechnical data, the field investigation was carried out between Shivpuri to Byasi along NH-7 in Garhwal, Uttarakhand. Then geotechnical data was intended followed by rock mass characteristic, kinematic analysis and $\mathrm{Q}_{\text {slope }}$ stability. Additionally, to review the stability results, numerical simulation (finite element method) was employed and slope mass behavior and failure mechanism of cut slopes were also evaluated. The rock mass characteristic and kinematic analysis illustrate normal and good variety of rock mass mainly wedge mode with flexural toppling of failure. The slope mass rating, continuous slope mass rating and also $\mathrm{Q}_{\text {slope }}$ stability analysis showed, road cut slopes are critically stable and unstable. The results of different empirical methods shows a decent correlation between them. Further the numerical simulation analysis also evaluates that two cut slopes are unstable and other one is critically stable. This substantial empirical and numerical analysis of cut slopes provides a collective approach to stable and develop the holistic road corridor in Himalayan terrain.
\end{abstract}

Keywords: Rock mass characteristic, Slope mass rating, Continuous slope mass rating, $\mathrm{Q}_{\text {slope }}$ stability, Numerical simulation

\section{Introduction}

Landslides in jointed rock slopes are one of the most incessant natural and anthropogenic hazards that have been frequently recorded in Himalayan terrain of the Uttarakhand region, India. Uttarakhand state has witnessed for the occurrence of large-scale landslides as well as numerous small-scale landslides over the years. According to Geological Survey of India, India has 0.42 million $\mathrm{km}^{2}$ (12.6\% of land area) landslide prone 
areas, of which 0.04 million $\mathrm{km}^{2}$ falls in Uttarakhand state. In Uttarakhand, RishikeshBadrinath (Mana) NH-7 is significant path for the transportation, public tourism and socio-economic activities. This mountainous road corridor is also a prime medium for religious activity, where pilgrims use this route to reach their respective shrine and temples located in northern proximity of Uttarakhand.

The Himalayan terrain is tectonically active, deformed and dissected by various unfavourable and oriented discontinuities. The variation in rain and temperature throughout the year, make this region more susceptible to slope failure. Also, increase in population imposes immense pressure on existing infrastructure of the Himalayan region and anthropogenic activity such as road development, tunnel and hydroelectric projects enhanced the frequency of occurrences of landslides in valley [24, 42, 43]. Majority of landslides occurred along NH-7 initiated from cut slopes which are poorly designed, excavated and left unsupported, affecting the road alignment and become prone to failure during rainy season $[1,28,39,42]$. Percolation of water through weak fracture and joint plane exposed the overburden mass resting on the cut slopes and slip it down slope [53].

Varnes [51, 52] and Cruden [11] classified the earth movements downslope based on multiple processes involved such as rock and debris slide, block topple, rock fall, earth flow, avalanches. Such processes largely controlled by failure mechanism, rock type and prevailing geo-hydrological and geotechnical conditions. In recent past, several occurrences of massive landslide have caused large-scale human calamity, material and infrastructural damage and associated environmental, topography and social hazards in lesser Himalayan region [39]. The occurrence of any such hazard is devastating and the resulting effect become worse when one event triggers another, such as flash flood induced landslides of Kedarnath in June, 2013 along the entire stretch of GangaAlaknanda valley. Considering numerous challenges in slope stability, optimum and stable slope design is a major concern for authorities along NH-7. Therefore, it is required to predict the failure mechanism, factor of safety and vulnerable portions of cut slope to avoid any casualty due to rock mass failure [28].

In past few years several authors have performed stability analysis using conventional and numerical method of different road sections of mighty Himalayan terrain and suggested instability conditions/mechanism and general method to enhance the stability of cut slopes. Sati et al. [39] carried out stability appraisal of landslide in Uttarakhand and suggested that intensity of fresh slides is higher in the newly cut road sections, however due to reactivation and enlargement of existing landslides voluminous dimension of slides is higher as compared to new road cuts. Apart from providing cause and occurrences of many slope failures, the author has not carried out stability assessment of particular slope and recommended other agencies/department/researcher to devise methodology for the prediction of stability. Further with time many authors have done slope stability and landslide analysis in jointed rock slopes of Himalayan/mountainous region and several other part of the world [1,30-32, 37, 38, 41, 44].

The present study was undertaken along NH-7 between Shivpuri to Byasi, in Uttarakhand, where three cut slopes were selected to understand the rock mass characteristics and slope behavior exclusively in steep jointed phyllitic quartzite rock mass. This paper presents the rock mass characteristics (GSI and $\mathrm{RMR}_{\text {basic }}$ ) and slope stability evaluation 


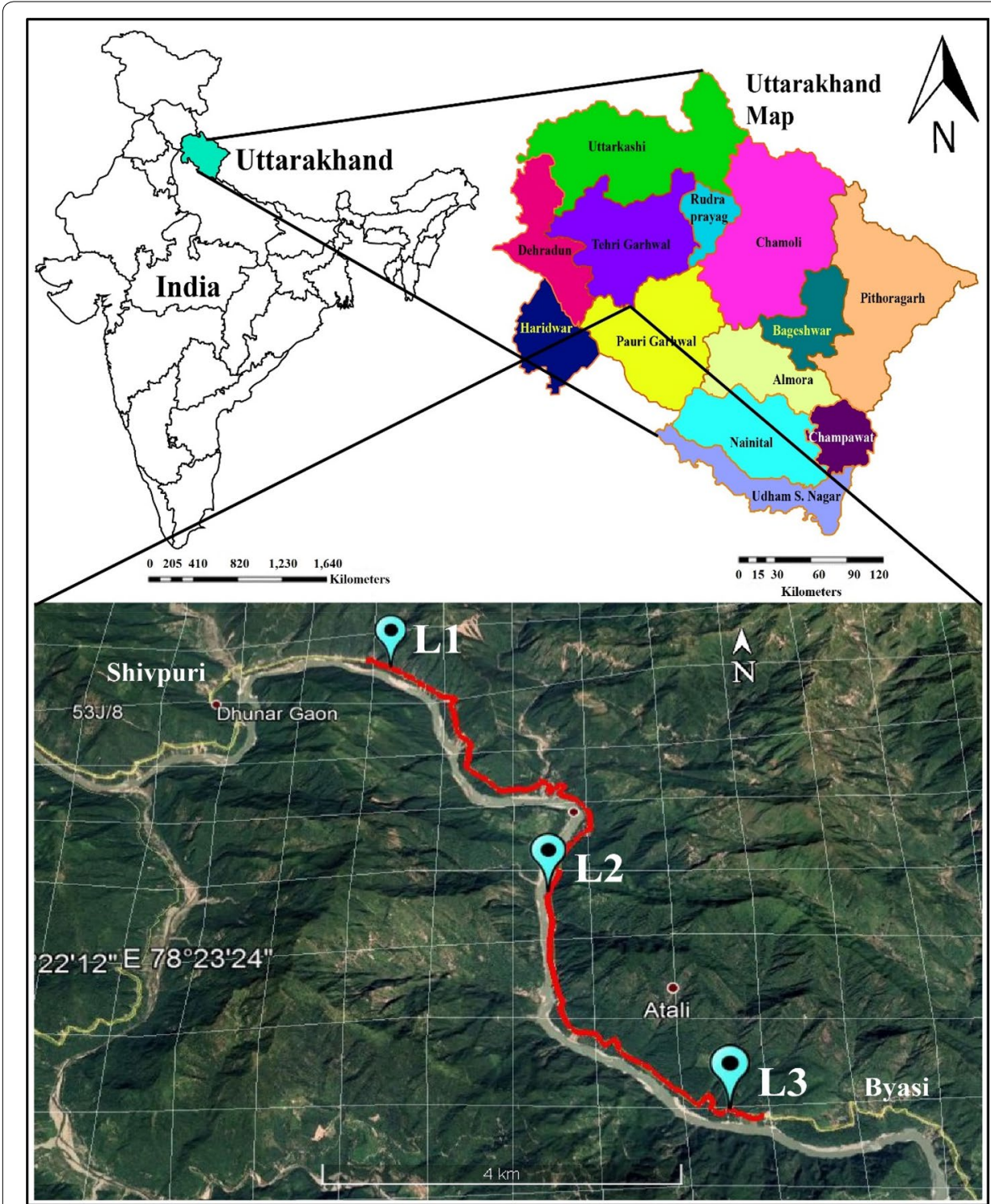

Fig. 1 Location map of investigated area (L1-L3)

through empirical methods (SMR, CoSMR and $\mathrm{Q}_{\text {slope }}$ stability) with kinematic analysis. Further, numerical simulation has been done with continuum 2D elasto-plastic finite element method to acquire about failure mechanism, factor of safety (or critical SRF) and to demarcate the vulnerable portions of cut slope.

\section{Study area}

Uttarakhand state encompasses vast exposure of hilly terrain which is broadly categorized into Kumaun and Garhwal regions. The investigated area lies in Survey of India toposheet no. 53//8 in Garhwal region. The studied cut slopes are located along NH-7 between Shivpuri to Byasi that runs parallel to the holy Ganga river valley (Fig. 1). National Highway (NH-7) passes through worst landslide prone area of Lesser Himalayan, where three locations between Byasi and Shivpuri were chosen for detailed slope stability assessment by an empirical and an advance numerical technique. 
Table 1 Attributes of discontinuities and various geotechnical parameter with their coordinates

\begin{tabular}{|c|c|c|c|c|c|}
\hline \multirow{2}{*}{$\begin{array}{l}\text { Location } \\
\text { Latitude/ } \\
\text { Longitude }\end{array}$} & \multicolumn{4}{|l|}{ Joint } & \multirow{2}{*}{$\begin{array}{l}\text { Slope orientation/ } \\
\text { Lithology }\end{array}$} \\
\hline & Parameters & $J_{1}$ & $J_{2}$ & $J_{3}$ & \\
\hline \multirow{8}{*}{$\begin{array}{l}\text { L1 } \\
30^{\circ} 08^{\prime} 10.30^{\prime \prime} N \\
78^{\circ} 24^{\prime} 42.42^{\prime \prime} \mathrm{E}\end{array}$} & Joint orientation & $45^{\circ} / \mathrm{N} 38^{\circ}$ & $72^{\circ} / \mathrm{N} 290^{\circ}$ & $70^{\circ} / \mathrm{N} 198^{\circ}$ & \multirow{8}{*}{$\begin{array}{l}70^{\circ} / \mathrm{N} 240^{\circ} \\
\text { Tal } \\
\text { Phyllitic quartzite } \\
\text { (loosely com- } \\
\text { pacted) }\end{array}$} \\
\hline & Persistence (m) & $0.18-0.74$ & $0.1-0.68$ & $0.1-0.5$ & \\
\hline & Aperture (mm) & $1-5$ & $0.1-1$ & $0.1-1$ & \\
\hline & $\begin{array}{l}\text { Average spacing } \\
(\mathrm{m})\end{array}$ & 0.39 & 0.29 & 0.05 & \\
\hline & Roughness & Rough & Smooth & Slightly rough & \\
\hline & Weathering & Moderately & Moderately & Moderately & \\
\hline & Infilling & Soft $<5 \mathrm{~mm}$ & Soft $<5 \mathrm{~mm}$ & Soft $<5 \mathrm{~mm}$ & \\
\hline & Water condition & Dry & Dry & Dry & \\
\hline \multirow{8}{*}{$\begin{array}{l}\mathrm{L} 2 \\
30^{\circ} 05^{\prime} 56.77^{\prime \prime} \mathrm{N} \\
78^{\circ} 26^{\prime} 04.26^{\prime \prime} \mathrm{E}\end{array}$} & Joint orientation & $58^{\circ} / \mathrm{N} 200^{\circ}$ & $60^{\circ} / \mathrm{N} 315^{\circ}$ & $57^{\circ} / \mathrm{N} 85^{\circ}$ & \multirow{8}{*}{$\begin{array}{l}65^{\circ} / \mathrm{N} 270^{\circ} \\
\text { Tal } \\
\text { Phyllitic quartzite } \\
\text { (moderately } \\
\text { compacted) }\end{array}$} \\
\hline & Persistence (m) & $1-20$ & $1-5$ & $0.5-3.8$ & \\
\hline & Aperture (mm) & $0.1-1$ & $1-5$ & $>5$ & \\
\hline & $\begin{array}{l}\text { Average spacing } \\
(\mathrm{m})\end{array}$ & 1.22 & 0.54 & 0.5 & \\
\hline & Roughness & Slightly rough & Slightly rough & Slightly rough & \\
\hline & Weathering & Moderately & Moderately & Moderately & \\
\hline & Infilling & None & Hard $<5 \mathrm{~mm}$ & Hard $>5 \mathrm{~mm}$ & \\
\hline & Water condition & Dry & Dry & Dry & \\
\hline \multirow{8}{*}{$\begin{array}{l}\text { L3 } \\
30^{\circ} 04^{\prime} 11.09^{\prime \prime} \mathrm{N} \\
78^{\circ} 27^{\prime} 20.68^{\prime \prime} \mathrm{E}\end{array}$} & Joint orientation & $70^{\circ} / \mathrm{N} 130^{\circ}$ & $55^{\circ} / \mathrm{N} 205^{\circ}$ & $72^{\circ} / \mathrm{N} 302^{\circ}$ & \multirow{8}{*}{$\begin{array}{l}73^{\circ} / \mathrm{N} 155^{\circ} \\
\text { Tal } \\
\text { Phyllitic quartzite } \\
\text { (moderately } \\
\text { compacted) }\end{array}$} \\
\hline & Persistence (m) & $0.5-5$ & $0.3-1.8$ & $0.2-1.25$ & \\
\hline & Aperture (mm) & $1-5$ & $1-5$ & $1-5$ & \\
\hline & $\begin{array}{l}\text { Average spacing } \\
(\mathrm{m})\end{array}$ & 0.85 & 0.65 & 0.4 & \\
\hline & Roughness & Rough & Slightly rough & Smooth & \\
\hline & Weathering & Moderately & Moderately & Moderately & \\
\hline & Infilling & Hard $<5 \mathrm{~mm}$ & Hard $<5 \mathrm{~mm}$ & Hard $<5 \mathrm{~mm}$ & \\
\hline & Water condition & Dry & Dry & Dry & \\
\hline
\end{tabular}

The rocks of the area mainly belong to the Garhwal syncline of the Lesser Himalayan. The different meta-sedimentary litho-groups of the syncline belong to Blaini Formation (shale, siltstone, phyllite and conglomerates), Infra-Krol Formation (limestone), Krol Formation (calcareous rocks), lower and upper Tal formation (arenaceous, argillaceous, quartzite and phyllitic quartzite) ranging from Proterozoic to Cambrian in age [50]. The geotechnical parameters such as slope height with their angle, joint orientation, spacing and persistence of discontinuities, roughness, number of joints, separation (aperture), the condition of discontinuities and groundwater condition for each cut slopes were recorded carefully in the field and shown in Table 1. Further, any loosening (or dislodged block) due to blasting and excavation or tropical rainfall erosion effect due to water condition or ice wedging was also measured. The generalized views of studied cut slopes with their existing conditions are shown in Fig. 2. 


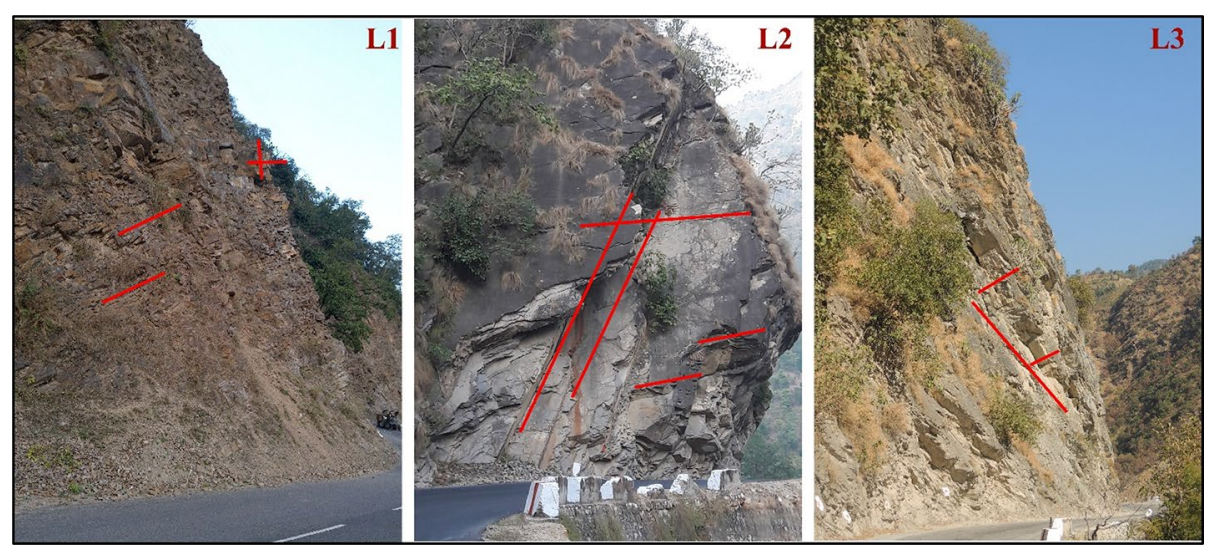

Fig. 2 L1 Indicate the extensive jointed, blocky slope having wedge failure; L2 Cut slope indicate two major joint and overhanging block above highway; and L3 Potential wedge formed by intersection of discontinuity on steep slope

\section{Methodology}

The paper focuses on the stability analysis of the three road cut sections which were selected based on their susceptibility, available in literature, landslide hazard zonation map and geological field survey. The field investigation was carried out to determine the rock masses exposed on slope surfaces, failure type, structural parameters and slope conditions. The representative rock samples were also collected from all locations, in order to determine various geotechnical properties of intact rock.

\section{Kinematics and rock mass characteristics}

The kinematic analysis is widely used to assess the potential modes of failure in jointed rock mass. The analysis is performed based on geometry of slope, material properties and angular relationships between discontinuities and slope surfaces [23, 40]. The kinematic analysis of all three road cut slopes were determined using DIPS 6.0 Rocscience Inc. [33] accordingly as Markland [27].

The rock mass rating (RMR) or Geomechanical classification was proposed by Bieniawski in (1979). Which provides quantitative, details and criterion for engineering design that refine the actual geological characteristics of rock mass. RMR system can be used to predict susceptibility of landslide and to select a method of excavation. It allows engineering geologist to demarcate the critical portion of rock mass on cut slope that could be prone to failure and accordingly suggest the required support system. $\mathrm{RMR}_{\text {basic }}$ was intended from five parameters such as uniaxial compressive strength (UCS) (in $\mathrm{MPa}$ ) of intact rock material; rock quality designation (RQD) (in \%); the spacing of discontinuities (in meters); conditions of discontinuities (in meters) and groundwater condition (L/min) as Bieniawski [9]. The RQD formula was given by Palmström [29] as shown in Eq. (1).

$$
\mathrm{RQD}=115-3.3 \mathrm{Jv}
$$

Where volumetric joint (Jv) was estimated by the number of joints in cubic meter volume of a rock mass. 
In 1997, Hoek and Brown endorsed that for poor quality of rock masses $(R M R<25)$, RMR system was difficult to apply as RQD in most of the weak and in highly jointed rock mass is zero. The authenticity of relationship between RMR and the constants of the Hoek-Brown failure criterion begins to fail for highly fractured and weak rock masses. Therefore, Hoek et al. [19], Marinos and Hoek [25, 26] developed the classification system of Geological strength index (GSI) to get over the limitations of RMR system and to provide qualitative assessment of rock masses. Further, Sonmez and Ulusay [45] modified the GSI chart of Marinos and Hoek $[25,26]$ to obtain more quantitative numerical basis, for the evaluation of GSI. Geologically it is very sound index and their application is easy in the field. The revised GSI chart of Sonmez and Ulusay [45] include the parameters of surface condition rating (SCR) and structural rating (SR), which can be calculated on the basis of Eqs. (2) and (3) respectively.

$$
\begin{aligned}
& \mathrm{SCR}=\mathrm{Rr}+\mathrm{Rw}+\mathrm{Rf} \\
& \mathrm{SR}=-17.5 \ln \mathrm{Jv}+79.8
\end{aligned}
$$

Where $\mathrm{Rr}=$ Roughness rating, $\mathrm{Rw}=$ Weathering rating, and $\mathrm{Rf}=$ Infilling rating, and $\mathrm{Jv}=$ Volumetric joint count.

\section{Empirical method of slope stability}

The worldwide classification system Slope Mass Rating (SMR) was established by Romana, in (1985) and very useful for the preliminary evaluation of slope stability. Irigaray et al. [21] suggested that the detailed quantitative definition of the correction factors of SMR classification is one of the most important advantages over RMR system. SMR systematically describes rock mass conditions and provides some basic mandate about potentially instable modes and the required support measures. The Slope Mass Rating (SMR) is calculated by determining four correction/adjustment factors to the basic RMR [9] as in Eq. (4).

$$
\mathrm{SMR}=\mathrm{RMR}_{\text {basic }}+\mathrm{F}_{1} \times \mathrm{F}_{2} \times \mathrm{F}_{3}+\mathrm{F}_{4}
$$

Where $F_{1}, F_{2}$ and $F_{3}$ are the adjustment factors and their value rely on the interrelationship between discontinuities, affecting slope's rock mass and one additional factor $F_{4}$ is related to method of excavation.

Continuous slope mass rating (CoSMR) proposed by Tomás et al. [47] is a modified version of SMR, which rectify the discrete nature of correction factors by the continuous functions. The CoSMR allocate distinct value of each adjustment factor $\left(\mathrm{F}_{1}, \mathrm{~F}_{2}\right.$, and $F_{3}$ ) unlike a range as in SMR. CoSMR is calculated from same equation of SMR given by Romana [36]. Where, the adjustment factors $F_{1}, F_{2}$ and $F_{3}$ are calculated by following continuous functions or Eqs. (5), (6) and (7) respectively.

$$
\mathrm{F}_{1}=\frac{16}{25}-\frac{3}{500} \arctan \left(\frac{1}{10}(|\mathrm{~A}|-17)\right)
$$




$$
\begin{aligned}
& \mathrm{F}_{2}=\frac{9}{16}+\frac{1}{195} \arctan \left(\frac{17}{100}(\mathrm{~B}-5)\right) \\
& \mathrm{F}_{3}=-30+\frac{1}{3} \arctan (\mathrm{C}) \text { (for planer and wedge failure), }
\end{aligned}
$$

and

$$
\mathrm{F}_{3}=-13-\frac{1}{7} \arctan (\mathrm{C}-120) \text { (for toppling failure) }
$$

Where A, B and C are the angles in degree and their values can be estimated from standard table given by Romana [36].

The quantitative methods RMR, SMR and continuous SMR were selected for the rock mass characterization and to suggest stable slope design. However, considerable drawback of the SMR method is to not include in the surficial discontinuity conditions and weathering effect in their final score calculation [21]. Moreover, Bar and Barton [5] stated that analytical approaches such as kinematics, limit equilibrium or finite element methods are cumbersome and it is practically impossible to assess the stability of rock cuttings and benches in real time. As in civil and mining projects, the excavation is usually too fast to perform such analysis.

Therefore, Bar and Barton [3, 5] proposed the somewhat modified Q-system [6, 7] known as $\mathrm{Q}_{\text {slope }}$ stability, and successfully applied [4] for the stability evaluation of slopes worldwide. The $\mathrm{Q}_{\text {slope }}$ is formulated by same six parameters RQD, $\mathrm{J}_{\mathrm{n}}, \mathrm{J}_{\mathrm{r}}, \mathrm{J}_{\mathrm{a}}, \mathrm{J}_{\mathrm{w}}$ and $\mathrm{SRF}$ as in $\mathrm{Q}$-System, but the term $\mathrm{J}_{\mathrm{w}}$, which is now replaced by $\mathrm{J}_{\text {wice, }}$, to incorporate wider range of environmental conditions (tropical intense rainfall effect, ice wedging etc.) and SRF with $\mathrm{SRF}_{\text {slope }}$ which is strength reduction factor for the slope. It has the following expression as in Eq. (8).

$$
\mathrm{Q}_{\text {slope }}=\frac{\mathrm{RQD}}{\mathrm{J}_{\mathrm{n}}} *\left(\frac{\mathrm{J}_{\mathrm{r}}}{\mathrm{J}_{\mathrm{a}}}\right)_{0} * \frac{\mathrm{J}_{\text {wice }}}{\mathrm{SRF}_{\text {slope }}}
$$

Where RQD is the rock quality designation, In is the joint set number, Jr is the joint roughness number, Ja is the joint alteration number, Jr/Ja included discontinuity orientation and wedge adjustment factor $(\mathrm{Jr} / \mathrm{Ja})_{0}, \mathrm{~J}_{\text {wice }}$ is the environmental and geological condition number, and $\mathrm{SRF}_{\text {slope }}$ is the strength reduction factor. Further, $\mathrm{SRF}_{\text {slope }}$ factor is divided into three parts, namely, $\mathrm{SRF}_{\mathrm{a}}$, physical condition number; $\mathrm{SRF}_{\mathrm{b}}$, stress-strength number, and $\mathrm{SRF}_{\mathrm{c}}$ major discontinuity number.

In compare to other methods, $\mathrm{Q}_{\text {slope }}$ stability classify the rock slopes in stable, unstable, and uncertain zones. It enables the engineering geologist to perform quick stability analysis and also provide the potential adjustments to slope angles for different probability of failure (PoF) to make stable slope design. This is distinguishable in field during excavation. The following Eq. (9) (For Probability of failure, PoF $=1 \%$ ) was used for adjustable slope angle calculation.

$$
\text { Slope angle } \beta^{\circ}=20 \log 10 \mathrm{Q}_{\text {slope }}+65^{\circ}
$$




\section{Numerical slope stability analysis}

Generally, the rock mass has inhomogeneous, intrinsically discontinuous, and anisotropic characteristics in nature [22]. In such media, analysis of deformation characteristics, mechanical behavior and failure mechanism is quite limited with deterministic traditional limit equilibrium method. To accomplish the limitations, numerical modelling has been applied in field of rock engineering to provide approximate solution to problems $[12,14,46]$. Finite element method (FEM) is most frequently used continuum numerical techniques due to their aptness to handle complex behavior of weak jointed and or heavily fractured rock mass problems [12, 48]. Unlike limit equilibrium (LEM) method, FEM does not rely on any presumed location of slip surface. FEM divides the material model into several small zone and utilizes Shear strength reduction (SSR) techniques in combination with material properties to estimate factor of safety and potential failure mechanism. Recently, many personnel have attempted numerical methods to simulate the behavior of jointed/blocky rock masses and soils in Himalayan condition $[15,24,28,42]$ and suggested the potential remedial measure for the long-term stability.

In present study, FEM analysis was performed using elasto- plastic plane strain simulator 'Phase ${ }^{2} 8.0$ ' Rocscience Inc. [34]. FEM is more applicable and has accessibility to handle complex problem under different conditions. To account several geotechnical parameters in analysis, material model such as Mohr-Coulomb and Hoek and Brown failure criterion have been well incorporated with FEM for the design of diverse slopes and underground excavations. Hoek [16] and Hoek et al. [18] established a good correlation between Hoek-Brown and Mohr-Coulomb failure criterion. Further, Hoek et al. [18] formulated an equation based on Hoek-Brown failure criterion and equivalent normal and shear stress of Balmer [2] to estimate equivalent Mohr-Coulomb friction angle and cohesion. In present analysis, Mohr-Coulomb failure criterion was applied for exact determination of failure mechanism and to demarcate susceptible portion of cut slope sections for instability.

\section{Results}

\section{Kinematics and rock mass characteristics}

Stereonet plot (equal angle projection) of each slope illustrates mainly the characteristics of double plane sliding i.e. wedge (W) failure for all locations. Along with wedge failure, also potential of flexural toppling (FT) failure at location L2 was prompted (Fig. 3). These predicted failures are mainly structurally controlled, where joint $\mathrm{J}_{2}$ is critical joint set to initiate mass failure on cut slopes. $\mathrm{RMR}_{\text {basic }}$ was intended from five different rock-mass parameters based on recorded field and laboratory estimated data for all three locations. Mean values of UCS ranges from 31.8 to $36.5 \mathrm{MPa}$ for phyllitic quartzite. Rating of different parameters for the $\mathrm{RMR}_{\text {basic }}$ with their result are shown in Table 2, where locations 1 and 3 are under 'fair' category, while location 2 has 'good' category of rock mass.

Table 3 indicate quantified GSI value, which was estimated by means of two parameters, i.e. 'surface condition rating' (SCR) and 'structure rating' (SR) as plotted in Fig. 4. The yellow color square as shown in Fig. 4 represent the quantified GSI value. The value of GSI indicate that all locations approximately fall in categories of blocky structure with fair surface condition. However, GSI value of locations 2 and 3 are slightly higher than location 1 due to blockier nature and high spacing between discontinuities. Low value of 


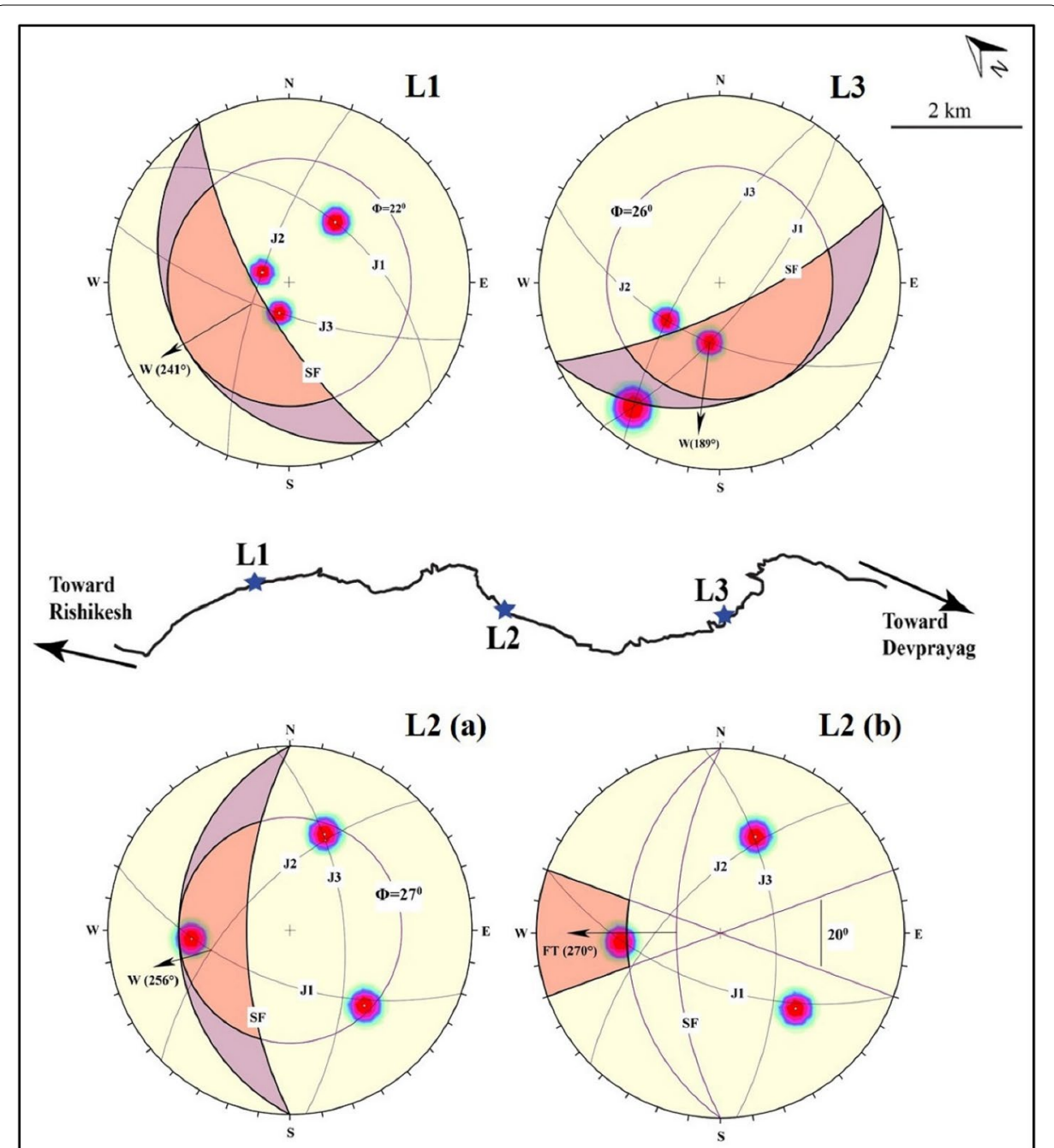

Fig. 3 Kinematic analysis of studied locations, indicating failure type and direction (shaded area shows possible failure envelope)

Table 2 Rating of parameters used for the estimation of $\mathbf{R M R}_{\text {basic }}$ [8]

\begin{tabular}{llcllll}
\hline Location & UCS & RQD & $\begin{array}{l}\text { Discontinuity } \\
\text { spacing }\end{array}$ & $\begin{array}{l}\text { Condition } \\
\text { of discontinuity } \\
\text { surface }\end{array}$ & $\begin{array}{l}\text { Groundwater } \\
\text { condition }\end{array}$ & RMR $_{\text {basic }}$ \\
\hline $\mathrm{L} 1$ & 4 & 8 & 8.3 & 17.6 & 15 & 52.9 \\
$\mathrm{~L} 2$ & 4 & 17 & 11.66 & 13.3 & 15 & 60.96 \\
$\mathrm{~L} 3$ & 4 & 13 & 13.33 & 14.33 & 15 & 59.66 \\
\hline
\end{tabular}

Table 3 Different parameters used for the estimation of GSI

\begin{tabular}{llllllll}
\hline Location & $\begin{array}{l}\text { Roughness } \\
\text { rating }\left(\mathbf{R}_{\mathbf{r}}\right)\end{array}$ & $\begin{array}{l}\text { Weathering } \\
\text { rating }\left(\mathbf{R}_{\mathbf{w}}\right)\end{array}$ & $\begin{array}{l}\text { Infilling } \\
\text { rating }\left(\mathbf{R}_{\mathbf{f}}\right)\end{array}$ & $\begin{array}{l}\mathbf{S C R} \\
\left(\mathbf{R}_{\mathbf{r}}+\mathbf{R}_{\mathbf{w}}+\mathbf{R}_{\mathbf{f}}\right)\end{array}$ & $J_{\mathbf{v}}$ & $\begin{array}{l}\mathbf{S R}=-\mathbf{1 7 . 5} \\
\text { In } \mathbf{J}_{\mathbf{v}}+\mathbf{7 9 . 8}\end{array}$ & GSI \\
\hline L1 & 3 & 3 & 2 & 8 & 19.8 & 27.55 & 34 \\
L2 & 3 & 3 & 4 & 10 & 11.5 & 37.05 & 42 \\
L3 & 3 & 3 & 4 & 10 & 15.35 & 32 & 40 \\
\hline
\end{tabular}




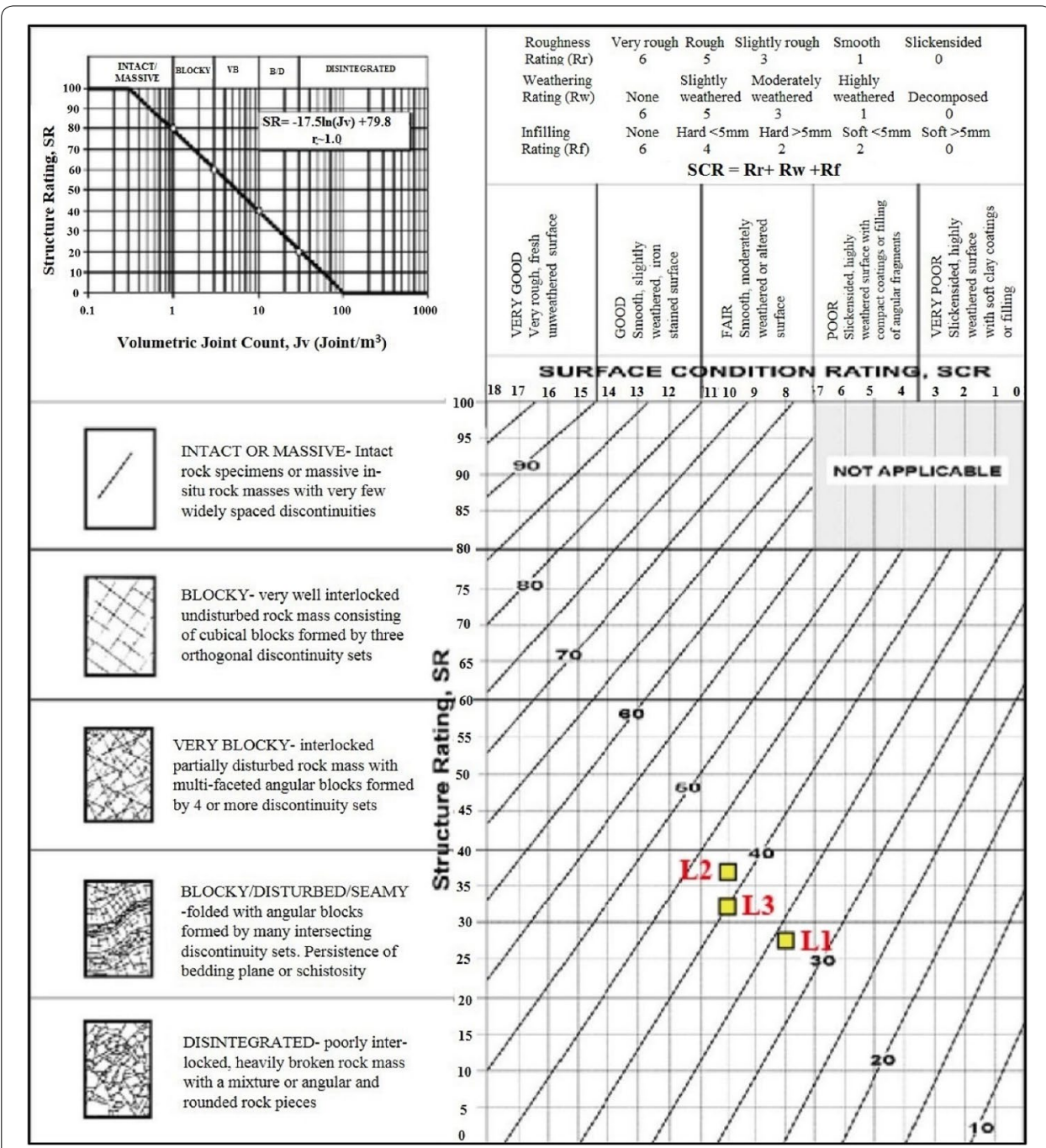

Fig. 4 Plot of estimated GSI values on chart provided by Sonmez and Ulusay [45]

GSI at location 1 may be due to extensive jointing ( 3 to 4 set) and poor surface condition of rock mass.

\section{Empirical slope stability analysis}

To calculate SMR, the rating has been assigned for each type of failure, which include the adjustment factors $F_{1}, F_{2}, F_{3}$ and $F_{4}$ as shown in Table 4. The result of SMR shows that location 1 is unstable while locations 2 and 3 are in partially stable condition. Similarly, continuous slope mass rating (CoSMR) was calculated according to Eq. (4) and the result shows that stability class is almost similar to the stability class of SMR (Table 5). Generally, the maximum vulnerability is obtained by CoSMR, as its final score is found to be less than the scores of discrete SMR. Moreover, SMR and CoSMR methods are most likely to give a preliminary assessment about instability condition and required support 


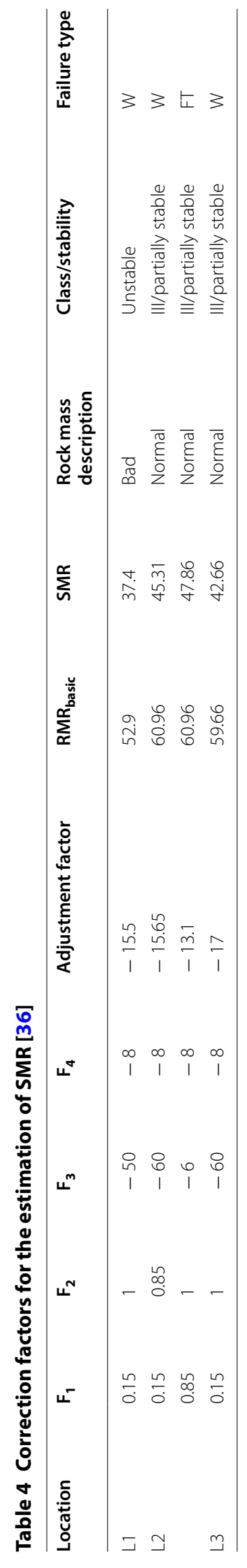


Table 5 Correction factors for the estimation of CoSMR [47]

\begin{tabular}{llllllllll}
\hline Location & $\mathbf{F}_{\mathbf{1}}$ & $\mathbf{F}_{\mathbf{2}}$ & $\mathbf{F}_{\mathbf{3}}$ & $\mathbf{F}_{\mathbf{4}}$ & $\begin{array}{l}\text { Adjustment } \\
\text { factor }\end{array}$ & $\mathbf{R M R}_{\text {basic }}$ & CoSMR & Class/stability & Failure type \\
\hline $\mathrm{L}_{1}$ & 0.15 & 0.97 & 57.28 & -8 & -16.35 & 52.9 & 36.54 & Unstable & $\mathrm{W}$ \\
$\mathrm{L} 2$ & 0.16 & 0.88 & -59.2 & -8 & -16.33 & 60.96 & 44.62 & III/partially stable & $\mathrm{W}$ \\
& 0.94 & 0.96 & -13 & -8 & -19.75 & 60.96 & 41.20 & III/partially stable & $\mathrm{FT}$ \\
$\mathrm{L} 3$ & 0.18 & 0.95 & -59.13 & -8 & -18.11 & 59.66 & 41.54 & III/partially stable & W \\
\hline
\end{tabular}

Table 6 Estimated $Q_{\text {slope }}$ parameters for all locations

\begin{tabular}{lllllllllll}
\hline Location & RQD \% & Rating RQD & $\begin{array}{l}\text { Rating } \\
\mathbf{J}_{\mathbf{n}}\end{array}$ & $\begin{array}{l}\text { Rating } \\
\mathbf{J}_{\mathbf{r}}\end{array}$ & $\begin{array}{l}\text { Rating } \\
\mathbf{J}_{\mathbf{a}}\end{array}$ & $\mathbf{S R F}_{\mathbf{a}}$ & $\mathbf{S R F}_{\mathbf{b}}$ & $\mathbf{S R F}_{\mathbf{c}}$ & $\mathbf{S R F}_{\text {slope }}$ & $\mathbf{J}_{\text {wice }}$ \\
\hline $\mathrm{L} 1$ & 50.81 & 8 & 6 & 3 & 2.16 & 5 & 2.64 & 1 & 8.64 & 0.3 \\
$\mathrm{~L} 2$ & 77.05 & 17 & 6 & 3 & 4 & 2.5 & 2.55 & 2 & 7.05 & 0.5 \\
$\mathrm{~L} 3$ & 64.34 & 13 & 6 & 3 & 1.33 & 2.5 & 2.5 & 1 & 6 & 0.3 \\
\hline
\end{tabular}

Table 7 Estimated $\mathbf{Q}_{\text {slope }}$ value and slope angle of all locations and their stability condition

\begin{tabular}{|c|c|c|c|c|c|c|c|}
\hline Location & RQD/Jn & $(\mathrm{Jr} / \mathrm{Ja})_{0}$ & Jwice/SRF $_{\text {slope }}$ & $\mathrm{Q}_{\text {slope }}$ & $\begin{array}{l}\text { Average slope } \\
\text { angle }\left({ }^{\circ}\right)\end{array}$ & $\left(\beta^{\circ}\right)$ & $\begin{array}{l}\text { Stability } \\
\text { condition } \\
\text { from data chart }\end{array}$ \\
\hline L1 & 8.46 & 1.38 & 0.034 & 0.40 & 70 & 57 & Unstable \\
\hline L2 & 12.84 & 0.75 & 0.070 & 0.68 & 65 & 61 & Critically unstable \\
\hline L3 & 10.72 & 2.25 & 0.05 & 1.20 & 73 & 66 & Critically unstable \\
\hline
\end{tabular}

measures. Similarly, the rating for the $\mathrm{Q}_{\text {slope }}$ parameters as shown in Eq. (8) was calculated (Table 6).

Estimated $\mathrm{Q}_{\text {slope }}$ values are shown in Table 7. Figure 5 shows that plot of $\mathrm{Q}_{\text {slope }}$ vs. average slope angle and $\beta$ angles of the investigated slope accordingly Bar and Barton [3]. Stability condition of each cut slope is marked with violet polygon, in data chart, where location 1 is unstable and rest of locations are critically stable (Fig. 5).

Bar and Barton [3] recommended that based on $\mathrm{Q}_{\text {slope }}$ value, it is possible to reduce the slope angle and change in design of cut slope during excavation process based on different probability of failures. $\beta$ angles for probability of failures $1 \%$ is calculated using Eq. (9) and shown in Table 7. Further, the $\mathrm{Q}_{\text {slope }}$ value with average slope angle (red star) and $\beta$ angles have also been plotted (violet star) for probability of failures $1 \%$, to improve the probability and stability of cut slopes (Fig. 5).

\section{Numerical simulation}

In-situ uniaxial compressive strength (UCS) of representative rock samples were estimated in the lab from universal testing machine (UTM) as per ISRM suggested methods [49]. The Roclab program [35] was used to determine rock mass properties, where input parameters are taken as-estimated GSI (Table 3), mean value of UCS (intact rock), unit weight $\left(0.027 \mathrm{MN} / \mathrm{m}^{3}\right)$, material constant and slope height. Table 8 shows the determined data for representative rock samples to assess the numerical 


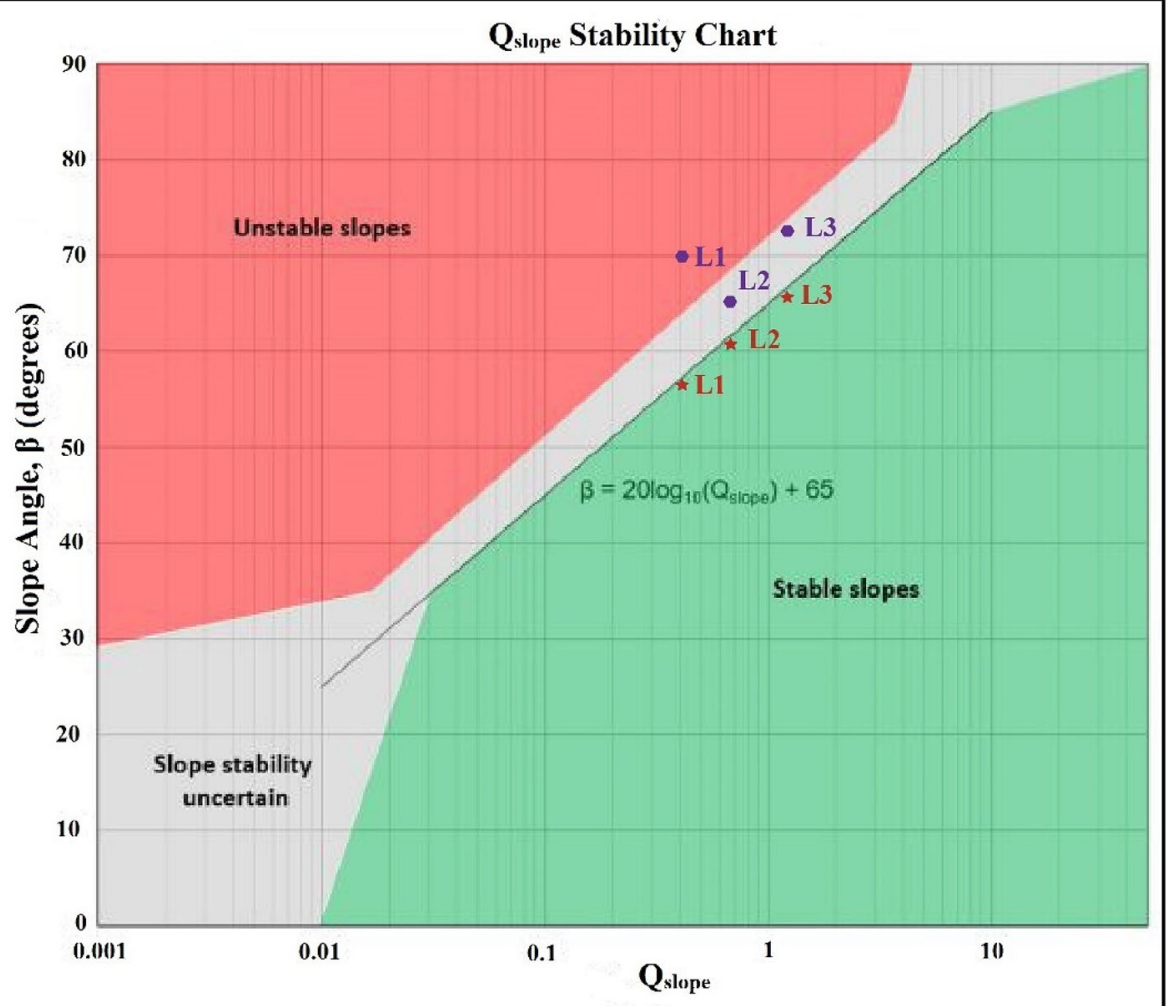

Fig. 5 Data plot of $Q_{\text {slope }} v$ s. average slope angle and $\beta$ angles of the investigated cut slopes

Table 8 Estimated data of representative rock samples for all locations

\begin{tabular}{llllll}
\hline Location & $\sigma_{c i}(\mathrm{MPa})$ & $\mathrm{C}(\mathrm{MPa})$ & $\boldsymbol{\Phi}\left(^{\circ}\right)$ & $\mathrm{E}(\mathrm{GPa})$ & $\begin{array}{l}\text { Slope } \\
\text { height } \\
(\mathbf{m})\end{array}$ \\
\hline $\mathrm{L} 1$ & & & & 55 \\
$\mathrm{~L} 2$ & 33.2 & 0.135 & 22 & 15.33 & 50 \\
$\mathrm{~L} 3$ & 36.5 & 0.181 & 27 & 16.86 & 55 \\
\hline
\end{tabular}

simulation. To analyze the investigated slopes, two dimensional plane strain condition has been considered with Gaussian elimination solver to resolve the equations. Steepest $2 \mathrm{D}$ profile for a slope has been incorporated in the model so that the profile with maximum vulnerability can be analyzed. The problem domain (2D slope profile) has been discretized and meshed through six nodded triangular elements to incorporate all the geometrical complexities. The base and the left boundary has been restrained in both $\mathrm{X}$ and $\mathrm{Y}$ direction as boundary conditions. The slope surface towards the road has been kept free and gravity loading, body forces and field stress were employed as initial element loading.

The extracted displacement contour and its distribution pattern across FE model represents the deformation intensity in different parts of the cut slope sections. The critical SRF as from numerical simulation result implies that slopes at location L1 


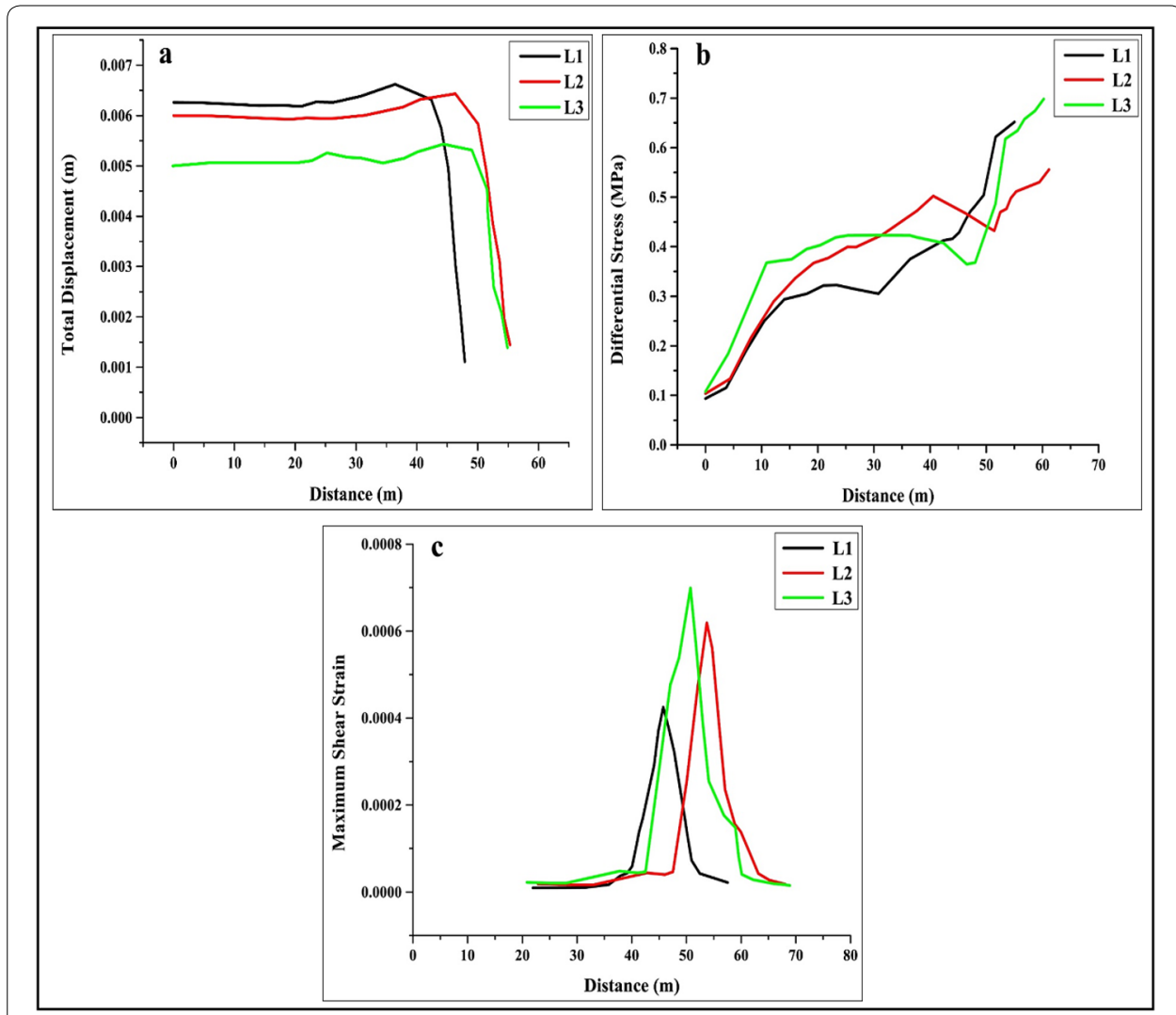

Fig. 6 a Total displacement vs. distance; $\mathbf{b}$ differential stress vs. distance; and $\mathbf{c}$ maximum shear strain vs. distance

(0.87) and location L3 (0.95) are unstable, while slope at location L2 (1.03) is critically stable. Among all the three locations, FEM analysis resulted maximum value of total displacement $(0.0066 \mathrm{~m})$, differential stress $(0.698 \mathrm{MPa})$ and maximum shear strain (0.00069) at most deformed section (near toe) of the cut slope. The graph as shown in Fig. $6 \mathrm{a}-\mathrm{c}$ represents the variation of total displacement, differential stress and maximum shear strain along the free face (apex to toe) of cut slope surfaces in the susceptible zone of failure. Further, the maximum value of these parameters was found at the toe of slope section and it was also being corroborated by field evidences.

\section{Analyses and discussion}

Bieniawski [10] suggested that it is essential to identify most critical condition of discrete geological features that mostly govern the stability of rock slopes. Whereas, Bieniawski [9] and Hoek and Brown [17] suggested that GSI can be correlated with the RMR and modified rock mass quality index Q. The result of RMR and GSI suggest that slopes has almost fair to good quality of rock with blocky structure and fair surface conditions. The calculated GSI value indicate that all locations approximately fall in categories of blocky structure with fair surface condition. However, GSI value of locations 2 and 3 are slightly higher than location 1 due to blockier nature and high spacing between discontinuities. Low value of GSI at location 1 may be due to 


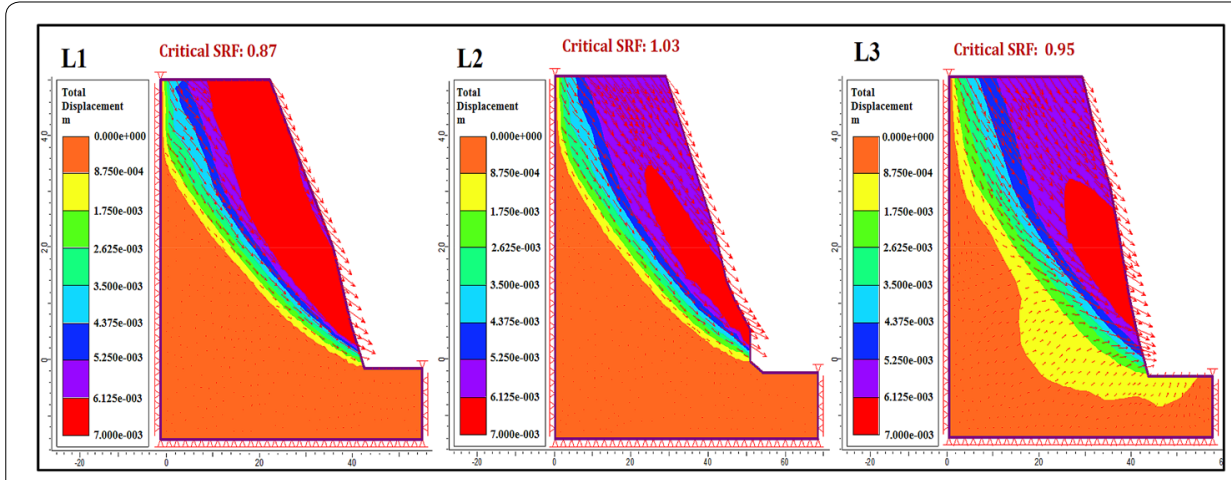

Fig. 7 Indicate the total displacement contour pattern generated from FE results to assess the possible extent of zone of failure (L1-L3)

extensive jointing (3 to 4 set) and poor surface condition of rock mass. Stability result of each cut slopes are also correlated for SMR and CoSMR, where slopes are mostly partially unstable (Tables 4 and 5). Generally, the maximum vulnerability is obtained by CoSMR as its final score is found to be less than the scores of discrete SMR. Moreover, SMR and CoSMR methods are most likely to give a preliminary assessment about instability condition and required support measures. The average of these two rating should be considered in the design of support systems for any forthcoming project. Further, the result of SMR and CoSMR techniques is also validated from $\mathrm{Q}$ slope stability classification system, where all the empirical results express a well correlation to each other.

In numerical simulation result, slope 1 and 3 are in unstable condition and slope 2 is critically stable. In Fig. 7 at location L1, the displacement contour of almost equal magnitude distributed along the entire length of slope face. It indicates that maximum failure zone has wide pattern near crest and gradually taper near toe of the slope, hence anticipating slight deeper zone of failure. Based on field observation and FEM result, it can be predicted that slope may undergo wedge (estimated from kinematic analysis) or possibly curvo-planar type of failure due to extensive jointing and smaller block size. At location L2 in Fig. 7 indicate that shallower damage zone is lying from mid portion to toe of slope face, clearly exhibited by maximum value of total displacement contour. Here, the slope angle $\left(65^{\circ}\right)$ is excavated in such a way that wedges are freely hanging on the roadside and discontinuity orientation across slope face also favours toppling failure (from kinematic analysis) (Fig. 3). The field data depict that at location L2, persistence of bedding joint is quite high $(1-20 \mathrm{~m})$ and excavation activity for further road development continuously disrupt rock masses. Due to which persistent joints are expected to get exposed, therefore enabling kinematic feasibility [13] across the slope face and anticipating thick block failure. Displacement contour pattern at location L3 (Fig. 7) shows that the most vulnerable part is distributed near middle portion of the free face which imply possibility of shallow zone of failure. However, due to high steepness of slope $\left(75^{\circ}\right)$ and intermittent joint and outward projected displacement contour with respect to slope face show potential for step path failure [20]. Further the impact of gravitational loading will be slightly higher for location 1 and $3(\mathrm{H} \sim 55 \mathrm{~m})$ than location $2(\mathrm{H} \sim 50 \mathrm{~m})$. Overall from 
empirical and numerical simulation analysis, the slope condition in present are critically stable to unstable i.e. vulnerable condition.

\section{Conclusion}

In present study, three road cut slopes have been investigated for their rock mass characteristics and stability analysis. The cut slopes are located from Shivpuri to Byasi along National Highway (NH)-7 in Pauri Garhwal region of Uttarakhand. Kinematic analysis showed wedge mode of failure in all locations with one toppling at location 2, which has also been noticed during field survey. The rock mass characteristics assessed by $\mathrm{RMR}_{\text {basic }}$ and GSI technique are almost similar result and revealed that rocks are good and fair quality, with blocky structure and fair surface condition. The discrete and continuous SMR techniques also showed that slopes are partially stable with almost similar stability class. To supplement the SMR and CoSMR result, $\mathrm{Q}_{\text {slope }}$ stability of cut slopes were assessed, that indicate that slope at location 1 is unstable while location 2 and 3 are partially stable, which also confirm from the result of SMR and CoSMR techniques. Further, to stable these slopes, $\beta$ angles have been derived for probability of failures $1 \%$. The numerical simulation (FEM) resulted that location $1 \& 3$ are unstable, while location 2 is critically stable. The analysis showed that shallow to intermediate zone of failure with maximum total displacement, differential stress and shear strain found near the toe of slope section. However, the slope at location 3 is partially stable under SMR/CoSMR and $\mathrm{Q}_{\text {slope }}$ system, whereas unstable in FEM model. All inclusive, the FEM and different empirical results revealed that studied road cut slopes between Shivpuri to Byasi in Uttarakhand are critically stable to unstable. Therefore, towards the stability, the sealing of discontinuities is required to install the grouting along the discontinuities surfaces. Thereafter, nets of the desired mesh or systematic bolting can be applied at vulnerable portions of slope face (as discussed) to minimize the potential threat such as any incidental rock fall or block failures.

\footnotetext{
Acknowledgements

The authors would like to thank Rock Science and Rock Engineering lab, IIT Bombay, India, for providing access to Rocscience programme and essential services to carry out all geotechnical testing.
}

\section{Authors' contributions}

HOS carried out field survey and all the geotechnical testing. HOS and TAA jointly carried out rock mass characteristics and slope stability analysis. HOS and TAA drafted this manuscript, while TNS and KHS gave valuable suggestions and correction. All authors read and approved the final manuscript.

\section{Competing interests}

The authors declare that they have no competing interests.

Received: 9 May 2020 Accepted: 14 September 2020

Published online: 02 December 2020

\section{References}

1. Ansari TA, Sharma KM, Singh TN (2019) Empirical slope stability assessment along the road corridor $\mathrm{NH}-7$, in the Lesser Himalayan. Geotech Geol Eng 37(6):5391-5407. https://doi.org/10.1007/s10706-019-00988-w

2. Balmer G (1952) A general analysis solution for Mohr's envelope. In: Proc. ASTM, vol 52, pp 1260-1271

3. Bar N, Barton N (2017) The Q-slope method for rock slope engineering. Rock Mech Rock Eng 50:3307-3322. https:// doi.org/10.1007/s00603-017-1305-0

4. Bar N, Barton N (2018) Rock slope design using Q-slope and geophysical survey data. Period Polytech Civil Eng 62(4):893-900

5. Barton N, Bar N (2015) Introducing the Q-slope method and its intended use within civil and mining engineering projects. In: Schubert K (ed) Future development of rock mechanics; Proc. ISRM reg. symp. EUROCK 2015 \& 64th Geomechanics Colloquium, Salzburg, 7-10 October 2015, pp 157-162 
6. Barton N, Lien R, Lunde J (1974) Engineering classification of rock masses for the design of tunnel support. Rock Mech 6:189-236. https://doi.org/10.1007/BF01239496

7. Barton NR, Grimstad E (2014) An illustrated guide to the Q-system following 40 years use in tunnelling. In house publisher, Oslo. Accessed 30 Oct 2015

8. Bieniawski ZT (1979) The geomechanics classification in rock engineering applications. In: 4th ISRM congress. International Society for Rock Mechanics and Rock Engineering

9. Bieniawski ZT (1989) Engineering rock mass classifications: a complete manual for engineers and geologists in mining, civil, and petroleum engineering. Wiley, New York

10. Bieniawski ZT (1993) Classification of rock masses for engineering: the RMR system and future trends. In: Rock testing and site characterization. Pergamon, pp 553-573

11. Cruden DM, Varnes DJ (1996) Landslides: investigation and mitigation. Chapter 3-Landslide types and processes. Transportation research board special report, (247)

12. Eberhardt E (2003) Rock slope stability analysis-utilization of advanced numerical techniques. Earth and Ocean sciences at UBC

13. Eberhardt E, Stead D, Coggan JS (2004) Numerical analysis of initiation and progressive failure in natural rock slopes—the 1991 Randa rockslide. Int J Rock Mech Min Sci 41(1):69-87. https://doi.org/10.1016/S1365 $-1609(03) 00076-5$

14. Griffiths DV, Lane PA (1999) Slope stability analysis by finite elements. Geotechnique 49(3):387-403. https://doi. org/10.1680/geot.1999.49.3.387

15. Gupta V, Bhasin RK, Kaynia AM, Kumar V, Saini AS, Tandon RS, Pabst T (2016) Finite element analysis of failed slope by shear strength reduction technique: a case study for Surabhi Resort Landslide, Mussoorie township, Garhwal Himalaya. Geomatics Nat Hazards Risk 7(5):1677-1690. https://doi.org/10.1080/19475705.2015.1102778

16. Hoek E (1990) Estimating Mohr-Coulomb friction and cohesion values from the Hoek-Brown failure criterion. In: Intnl. J. Rock Mech. \& Mining Sci. \& Geomechanics Abstracts, vol 12, no 3, pp 227-229

17. Hoek E, Brown ET (1997) Practical estimates of rock mass strength. Int J Rock Mech Min Sci 34(8):1165-1186. https:// doi.org/10.1016/S1365-1609(97)80069-X

18. Hoek E, Carranza-Torres C, Corkum B (2002) Hoek-Brown failure criterion-2002 edition. Proc. of NARMS-Tac 1(1):267-273

19. Hoek E, Marinos P, Benissi M (1998) Applicability of the Geological Strength Index (GSI) classification for very weak and sheared rock masses The case of the Athens Schist Formation. Bull. Eng. Geol. Environ. 57(2):151-160. https:// doi.org/10.1007/s100640050031

20. Huang B, Yin Y, Du C (2016) Risk management study on impulse waves generated by Hongyanzi landslide in Three Gorges Reservoir of China on June 24, 2015. Landslides 13(3):603-616. https://doi.org/10.1007/s10346-016-0702-x

21. Irigaray C, Fernández T, Chacón J (2003) Preliminary rock-slope-susceptibility assessment using GIS and the SMR classification. Nat Hazards 30(3):309-324. https://doi.org/10.1023/B:NHAZ.0000007178.44617.c6

22. Jing $L$ (2003) A review of techniques, advances and outstanding issues in numerical modelling for rock mechanics and rock engineering. Int J Rock Mech Min Sci 40(3):283-353. https://doi.org/10.1016/S1365-1609(03)00013-3

23. Kliche C (1999) Rock slope stability. Society for Mining, Metallurgy, and Exploration. Inc (SME), Englewood

24. Mahanta B, Singh HO, Singh PK, Kainthola A, Singh TN (2016) Stability analysis of potential failure zones along NH-305. India Nat Hazards 83(3):1341-1357. https://doi.org/10.1007/s11069-016-2396-8

25. Marinos P, Hoek E (2000) GSI: a geologically friendly tool for rock mass strength estimation. In: ISRM international symposium. International Society for Rock Mechanics and Rock Engineering

26. Marinos P, Hoek E (2001) Estimating the geotechnical properties of heterogeneous rock masses such as flysch. Bull Eng Geol Environ 60(2):85-92. https://doi.org/10.1007/s100640000090

27. Markland JT (1972) A useful technique for estimating the stability of rock slopes when the rigid wedge slide type of failure is expected. Interdepartmental Rock Mechanics Project. Imperial College of Science and Technology, London

28. Pain A, Kanungo DP, Sarkar S (2014) Rock slope stability assessment using finite element based modelling —examples from the Indian Himalayas. Geomech. Geoeng. 9(3):215-230. https://doi.org/10.1080/17486025.2014.883465

29. Palmstrom A (1982) The volumetric joint count - a useful and simple measure of the degree of rock mass jointing. In: International association of engineering geology, vol 4. International congress, pp 221-228

30. Park BS, Cho H, Youn SP, Lee SH (2011) Case study on stability analysis of phyllite rock slopes in national road construction. Int J Geo-Eng 3(3):41-52

31. Ramesh V, Mani S, Baskar M, Kavitha G, Anbazhagan S (2017) Landslide hazard zonation mapping and cut slope stability analyses along Yercaud ghat road (Kuppanur-Yercaud) section, Tamil Nadu. India Int J Geo-Eng 8(1):2

32. Rao KS, Singh T (2017) Two-dimensional finite element based parametric analysis of south portal slope, Rohtang Tunnel, India. Procedia Eng 173:1330-1333

33. Rocscience, Dips v 6.008 (2013) Stereographic projection program for the analysis and presentation of orientation based data. Rocscience Inc., Toronto

34. Rocscience, Phase2 v. 8.005 (2011) 2D finite element program for calculating stresses and estimating support around underground excavations. Rocscience Inc., Toronto

35. Rocscience, Roclab v 1.033 (2013) Rock mass strength analysis using the generalized Hoek- Brown failure criterion. Rocscience Inc., Toronto

36. Romana M (1985) New adjustment ratings for application of Bieniawski classification to slopes. In: Proceedings of the international symposium on role of rock mechanics, Zacatecas, Mexico, pp 49-53

37. Sah N, Kumar M, Upadhyay R, Dutt S (2018) Hill slope instability of Nainital City, Kumaun Lesser Himalaya, Uttarakhand, India. J Rock Mech. Geotech Eng 10(2):280-289. https://doi.org/10.1016/j.jrmge.2017.09.011

38. Sarkar S, Pandit K, Sharma M, Pippal A (2018) Risk assessment and stability analysis of a recent landslide at Vishnuprayag on the Rishikesh-Badrinath highway, Uttarakhand. India Curr Sci 114(7):1527

39. Sati SP, Sundriyal YP, Rana N, Dangwal S (2011) Recent landslides in Uttarakhand: nature's fury or human folly. Curr Sci 100(11):1617-1620 
40. Sazid M (2019) Analysis of rockfall hazards along NH-15: a case study of Al-Hada road. Int J Geo-Eng 10(1):1. https:// doi.org/10.1186/s40703-019-0097-3

41. Siddique T, Pradhan SP, Vishal V, Mondal MEA, Singh TN (2017) Stability assessment of Himalayan road cut slopes along National Highway 58. India Environ Earth Sci 76(22):759. https://doi.org/10.1007/s12665-017-7091-x

42. Singh HO, Ansari TA, Singh TN (2020) Singh KH (2020) Analytical and numerical stability analysis of road cut slopes in Garhwal Himalaya. India Geotech Geol Eng. https://doi.org/10.1007/s10706-020-01329-y

43. Singh PK, Kainthola A, Panthee S, Singh TN (2016) Rockfall analysis along transportation corridors in high hill slopes. Environ Earth Sci 75(5):441. https://doi.org/10.1007/s12665-016-5489-5

44. Singh R, Umrao RK, Singh TN (2014) Stability evaluation of road-cut slopes in the Lesser Himalaya of Uttarakhand, India: conventional and numerical approaches. Bull Eng Geol Environ 73(3):845-857. https://doi.org/10.1007/s1006 4-013-0532-1

45. Sonmez H, Ulusay R (2002) A discussion on the Hoek-Brown failure criterion and suggested modifications to the criterion verified by slope stability case studies. Yerbilimleri 26(1):77-99

46. Stead D, Eberhardt E, Coggan JS (2006) Developments in the characterization of complex rock slope deformation and failure using numerical modelling techniques. Eng Geol 83(1-3):217-235. https://doi.org/10.1016/j.engge 0.2005 .06 .033

47. Tomás R, Delgado J, Serón Gáñez JB (2007) Modification of slope mass rating (SMR) by continuous functions. https ://doi.org/10.1016/j.ijrmms.2007.02.004

48. Tschuchnigg F, Schweiger HF, Sloan SW (2015) Slope stability analysis by means of finite element limit analysis and finite element strength reduction techniques. Part I: Numerical studies considering non-associated plasticity. Comput Geotech 70:169-177. https://doi.org/10.1016/j.compgeo.2015.06.018

49. Ulusay R, Hudson JA (2007) ISRM: the complete ISRM suggested methods for rock characterization, testing and monitoring: 1974-2006. Kozan Ofset Matbaacilık San ve Tic Sti, Ankara

50. Valdiya KS (1980) The two intracrustal boundary thrusts of the Himalaya. Tectonophysics 66(4):323-348

51. Varnes DJ (1958) Landslide types and processes. Landslides Eng Pract 24:20-47

52. Varnes DJ (1984) Landslide hazard zonation: a review of principles and practice

53. Wyllie DC, Mah CW (2004) Rock slope engineering, civil and mining. 4thSPONPRESS

\section{Publisher's Note}

Springer Nature remains neutral with regard to jurisdictional claims in published maps and institutional affiliations.

\section{Submit your manuscript to a SpringerOpen ${ }^{\odot}$ journal and benefit from:}

- Convenient online submission

Rigorous peer review

- Open access: articles freely available online

- High visibility within the field

- Retaining the copyright to your article

Submit your next manuscript at $\mathbf{s p r i n g e r o p e n . c o m ~}$ 